\title{
Exploring Wheat Value Chain Focusing on Market Performance, Post-Harvest loss, and Supply Chain Management in Ethiopia: The Case of Arsi to Finfinnee Market Chain
}

\author{
Tadesse Kenea Amentae ${ }^{1}$, Tura Kaso Hamo ${ }^{2}$, Girma Gebresenbet ${ }^{1} \&$ David Ljungberg ${ }^{1}$ \\ ${ }^{1}$ Division of Logistics, Department of Energy and Technology, Swedish University of Agricultural Sciences, \\ Uppsala, Sweden \\ ${ }^{2}$ Department of Agribusiness and Value Chain Management, Ambo University, Ambo, Ethiopia \\ Correspondence: Tadesse Kenea Amentae, Division of Logistics, Department of Energy and Technology, \\ Swedish University of Agricultural Sciences, Post Code: 75007, Box: 7032, Uppsala, Sweden. Tel: \\ 46-762-878-286. E-mail: tadesse.kenea.amentae@slu.se
}

Received: March 15, $2017 \quad$ Accepted: April 10, $2017 \quad$ Online Published: July 15, 2017

doi:10.5539/jas.v9n8p22 URL: https://doi.org/10.5539/jas.v9n8p22

We are grateful to RELOAD project for funding the activities of this study.

\begin{abstract}
In this study the wheat value chain from one of the highest wheat producing areas in Ethiopia (Arsi zone of Oromia region) to central markets in Finfinnee/Addis Ababa was assessed focusing on market performance, post-harvest losses, and the potential of supply chain management to improve the chain.

Value chain analysis, questionnaire-based loss estimations, Tobit model for loss factor determination, structure-conduct-performance (S-C-P), four firm concentration ratio $\left(\mathrm{CR}_{4}\right)$, market and profit margins, and theory of supply chain management were used to evaluate the wheat value chain. Primary data were collected using a semi-structured survey questionnaire and interview of key informants. The data was analyzed using descriptive statistics and Tobit model in SPSS and Excel software.

The study identified producers and their cooperatives, collectors, wholesalers, retailers, and processors as primary actors. At these stages of the wheat chain, post-harvest losses reported were $21 \%, 3 \%, 4 \%, 6 \%$, and $5 \%$, respectively. With the highest loss happening at producers' stage, this stage was identified as loss-hot-spot point. The Ethiopian Grain Trade Enterprise was also identified as main actor connecting the flow of wheat between producers and consumers occasionally. An increase in a quintal of wheat production, bad storage facilities, and weather conditions caused in an increase in post-harvest losses of 5.18, 4.06 and $1.36 \mathrm{Kgs}$ per quintal, respectively, at $1 \%$ statistical significance.

The assessed wheat value chain was characterized by unfair share of benefit among the chain actors. The producers who were in a position of adding the highest portion of value to the wheat received only $16 \%$ of the profit margin. The traders jointly and processors shared $33 \%$ and $51 \%$ of the profit margin, respectively. The $\mathrm{CR}_{4}$ assessments in the major wheat markets along the chain noted that with $\mathrm{CR}_{4}$ in Etaya (26.8), Asala (37.7), Adama (41.4), and Finfinnee (42.8), the wheat markets near the producers were more competitive than the central ones. Assessment on the degree of clearness noted that for $54 \%$ of the chain actors, it was very difficult to get reliable information about the whole wheat market along the chain. Licensing procedure, capital, and competitions were reported as barriers to wheat market entry.

For all producers, retailers, and collectors on agreement with their suppliers, the only means of agreement in doing business with their transaction partners were spot-market. However, $63 \%$ and $16 \%$ of collectors had oral and written contractual agreements, respectively, with their buyers. $36 \%$ and $31 \%$ of wholesalers reported they had oral contracts with their suppliers and buyers, respectively; $18 \%$ and $12 \%$ of them had written contracts with suppliers and buyers, respectively. Similarly, $42 \%$ and $9 \%$ of the processors had oral agreement with their suppliers and buyers while $23 \%$ and $27 \%$ of them had written contract agreement with their suppliers and buyers, respectively.
\end{abstract}


The study noted that the wheat chain assessed was characterized by disintegrated chain where businesses were self-oriented and mutualism has not well-developed. Working towards supply chain management and relational view of business has been recommended based on the problems identified in the study.

Keywords: Ethiopia, market-performance, post-harvest-loss, SCM, value-chain, wheat

\section{Introduction}

\subsection{Background}

Agriculture has always been an important sector in Ethiopia. According to FAO (2016), about $82 \%$ of the population was employed in agriculture. Agriculture contributed about $36 \%$ of the gross domestic product and about $81 \%$ of the total export income of the country during the year 2015/2016 (CIA, 2016).

In Ethiopia, cereal production and marketing is the means of livelihood for millions of smallholder households and it constitutes the single largest sub-sector in the economy. According to CSA (2012/13), cereals farming covered $78 \%$ of land under cultivation and $85 \%$ of total grain crop production. Hence, the concern over market performances and food losses across the supply and marketing chains needs to be the center of the countries' policy formulation and implementation. This leads the conclusion that research is critically important to support policy formulation. Particularly, in Ethiopia and similar developing countries, government policies have been more focused on aspects of production and less on what happens in between production and consumption.

Wheat is one of the most important cereals cultivated in Ethiopia. Wheat products contributed to $14 \%$ of the total caloric intake in Ethiopia, which made wheat the second most important food, behind maize (19\%) FAO (2014) as cited in (Kasa et al., 2015). It ranks fourth after Teff, Maize and Sorghum in area coverage and third in total production (CSA, 2012/13). According to the same source, wheat contributes to about $15 \%$ of total annual grain productions in Ethiopia.

Some studies indicated that the magnitude of wheat post-harvest loss in Ethiopia was significant ranging from $10 \%$ to $20 \%$ (Hodges et al., 2011). This figure is quite large especially for Ethiopia where a great majority of people are food insecure (WFP, 2014). It is ironical that the immediate victims of food insecurity have been producers, i.e., the very producers of food.

In Ethiopia, wheat is produced by smallholder producers, state farms, and commercial farms. The production is dominated by smallholder and almost all wheat producers in the country produce under rain-fed conditions. According to FAO (2014), the largest volume of wheat production originates from Oromia (57.5\%), where almost all zones of Oromia region grow wheat. However, Arsi, West Arsi, Bale, West Shewa, East Shewa and South West Shewa are the major wheat producing zones in order of production volume rank in the region. With annual production of about 1.5 million tons, the six zones contributed to more than $80 \%$ of the wheat production of the region (FAO, 2014). The Arsi and Bale areas are usually called as Ethiopia's wheat belt.

Even though Ethiopia has high potential for the production of wheat, the product supply and productions were not in response to customers' needs. In addition to this, poor linkage and post-harvest losses of wheat were estimated at high percent; this means that large amount of wheat produced never reaches the consumer and the effort and resource required to produce it are lost-forever. Reduction in this loss, particularly if it can economically be avoided, would be of great significance to growers and consumers.

It is important to recognize that food supply chain management (FSCM) practices and capacities (not only production and marketing) are important for many reasons including the achievement of food security objective. Ideally, a better food supply chain management capacity and practice would minimize the magnitude of losses (Kummu et al., 2012). This has positive impact to the potential employment and income linkage effects and gains from the activities across the food supply chains. Unfortunately, this crucial area has not received the attention it deserves among researchers and policy makers, particularly in developing countries like Ethiopia.

So as to improve the fundamental contribution of wheat to the economic growth of the country, it is important to explore the market performances and possibilities to reduce post-harvest losses across the supply and marketing chains. Therefore, this study aims at exploring the potential of supply chain management to improve market performances and reduce wheat losses in Ethiopia in the study area.

\subsection{Objectives of the Study}

The main objective of the study was to explore wheat value chain focusing on market performance, post-harvest loss, and supply chain management in the study area. 
The specific objectives of the study were to:

1) Map out and analyze wheat supply and marketing chains in the study area and its link to the central market,

2) Estimate the losses of wheat at all stages of wheat value chain and to identify factors responsible for the losses,

3) Identify value distribution among wheat value chain actors and to characterize the wheat market structure across the supply and marketing chains, and

4) Explore the situation of supply chain management (SCM) and it's potential to improve the market performance and to reduce losses in the wheat value chain in the study area.

\subsection{Significance of the Study}

The study identified gaps and potential solutions in wheat value chain related to the market performance, value-share among chain actors, and losses which serve policy directions and to develop the institutional arrangements to improve wheat production, producers' economic position, marketing, and consumptions. The other benefit that would be anticipated from this study is its significance as a source of literature for further studies of food grain supply chain management and post-harvest losses along supply chains.

\section{Method}

\subsection{Description of Study Area}

This study was undertaken making two districts (the second stage from the bottom of administrative structure), Hetosa and Tiyo of Arsi zone of Oromia regional state, in south eastern part of Ethiopia as the starting point of the wheat value chain and went to the central market in Finfinnee/Addis Ababa, the capital of Ethiopia. The two source districts were purposefully selected for its high productions and the route selected is among the major wheat trade routes in Ethiopia. Figure 1 represents the position of Ethiopia on global map, and the study area including the selected trade route (major markets) assessed by this study.
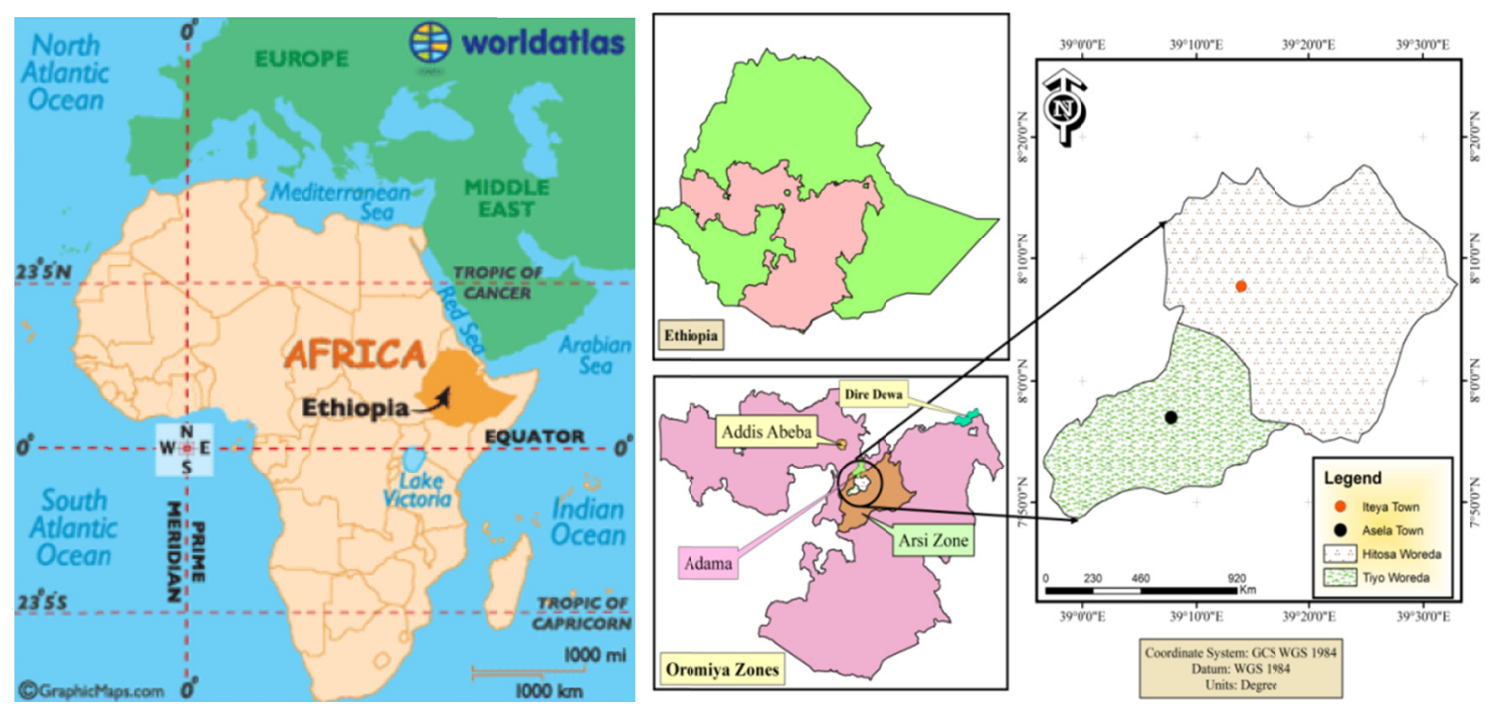

Figure 1. Position of Ethiopia on global map (left) and locations of the study area (right)

\subsection{Methods of Data Collection}

Qualitative and quantitative types of data were collected from both primary and secondary data sources. The primary data of both types were collected from main supply chain actors such as producers, collectors, cooperatives, traders, processors, and consumers using semi-structured questionnaires, interview of key informants, and observations. For loss estimation, the questionnaire based loss estimation method was used where the chain actors were asked the percentages of losses at their respective stage from what they hold during a year. Secondary data was taken from published and non-published reports and studies. Statistical reports from Ethiopian Central Statistical Agency (CSA), Bureau of Agriculture, and Research Centers were examples of sources of secondary data used beside published literatures. 


\subsection{Sampling Procedure and Sample Size}

Three-stages of sampling technique were implemented to select wheat producer at kebele level (the first/bottom stage of administrative structure) and sample of farmer households. In the first stage, with the consultation of districts' agricultural experts and development agents, two districts namely Hetosa and Tiyo of Arsi zone of Oromia regional state were selected. In the second stage, out of 23 and 21 kebeles of Hetosa and Tiyo districts, 3 and 4 wheat producer kebeles, respectively, were purposively selected based on the high level of production. In the third stage, from the selected rural kebeles, given the available resource and time at the disposal of the researchers, using the household list of the sampled kebeles 150 (60 Hetosa districts and 90 in Tiyo districts) sample producers were selected randomly based on proportional to the population size of the selected kebeles and sample size determination formula by Cochran (1963:75) as cited in Israel (1992), i.e., calculating a sample size using proportions as given in Equation (1), which gave 150 samples:

$$
n_{\mathrm{o}}=\frac{Z^{2} p \cdot q}{e^{2}}
$$

Where, $n_{\mathrm{o}}$ is the sample size, $Z^{2}$ is the abscissa of the normal curve that cuts off an area $\alpha$ at the tails $(1-\alpha$ equals the desired confidence level, e.g., 95\%), $e$ is the desired level of precision, $\mathrm{p}$ is the estimated proportion of an attribute that is present in the population, and $q$ is $1-p$.

Data from traders and consumers were included in the following manner. The lists of wholesalers were obtained from the respective districts of office of trade and industry. According to the office of trade and industry of the respective districts, there were 45 and 55 wholesalers in the Hetosa and Tiyo districts, respectively. Accordingly, 20 and 25 wholesalers were selected randomly from Hetosa and Tiyo districts, respectively. Totally, 45 wholesalers from the two districts were included. For other traders such as retailers and collectors, there were no recorded lists. Hence, snowball sampling was used in the market place where a retailer and/or collector, who was willingly interviewed recommended his/her collogue for the same. In this way, a total of 40 retailers and 25 collectors from the area were included. Moreover, in the wheat trade route to Finfinnee, totally, 85 wholesalers, 15 millers, and 3 flour factory from Iteya, Asella, Adama and Finfinnee markets were included purposefully with the main criteria as willingness to cooperate and being major wheat trader and actors in respective markets. For calculation of market concentration total traders' sales volume in Iteya and Asela markets and about one hundred traders' sales volume in Adama and Finfinnee markets were used. Hetosa Farmer's cooperative union was also included in the assessment.

Table 1. Distributions of sample farmer households across districts and sampled Kebeles

\begin{tabular}{lllll}
\hline Districts & Kebeles & Number of households & Proportion & Sample house holds \\
\hline Hetosa & Bonayaeda'o & 860 & 0.2 & 25 \\
& Borulenca & 413 & 0.1 & 23 \\
& Seroankato & 818 & 0.1 & 12 \\
& Subtotal & 2091 & 0.4 & 60 \\
\hline Tiyo & Dosha & 669 & 0.1 & 21 \\
& Gora silingo & 750 & 0.2 & 23 \\
& Hate & 779 & 0.2 & 24 \\
& Oda & 672 & 0.1 & 22 \\
& Subtotal & 2870 & 0.6 & 90 \\
\hline Total & & 4961 & 1 & 150 \\
\hline
\end{tabular}

\subsection{Data Analysis}

Descriptive statistics, value-chain analysis, and econometric analysis were used for analyzing the collected data.

\subsubsection{Value Chain Analysis}

According to Kaplinsky and Morris (2001), as the products move successively through the various stages, transactions take place between multiple chain actors, money and information are exchanged and value is progressively added. In this study, the analysis of wheat value chains highlighted the need for fair share of values created along the chain, enhancement of product quality, quantitative measurement of value obtained along the chain, promotion of coordinated linkages among chain actors, and overall improvement of the competitive position of individual chain actors in the wheat marketplaces. 
The following two steps of value chain analysis were applied in this study:

1) Mapping the value chain to understand the characteristics of the chain actors and the relationships among them, including the study of all actors in the chain, along the flow of wheat, information, and money through the chain;

2) Identifying the distribution of actors' benefits in the chain. This involved analyzing the market and profits margins within the chain and therefore determines who benefits from participating in the chain and who would need support to improve performance and gains.

In the prevailed context of market liberalization, the second step mentioned above is particularly important, since the poor, particularly the producers, involved in value chains were usually the most vulnerable in terms of lesser share in gains, i.e., in non-polite wording, exploited by other actors in the chain. Hence, analyzing the value-share among the chain actors serve to identify the distribution of benefits among the actors in order to design and implement a policy and directions for fair benefit sharing among all chain actors in the selected food value chain, in this case wheat.

To determine the actors benefit share, it is better to see the structure, conduct, and performance (S-C-P), of the market across the chain, which examines the causal relationships between market structure, conduct, and performance, and is usually referred to as the structure conduct and performance (S-C-P) model. Few authors also used this model to evaluate market performances in Ethiopia (Aysheshm, 2007; Rehima, 2006; Wolday, 1994; Dessalegn et al., 1998).

Market Concentration Ratio: The concentration ratio is a way of measuring the concentration of market share held by particular suppliers in a market. It is the percentage of total market sales accounted for by a given number of leading firms. Thus, a four-firm concentration ratio is the total market share of the four firms with the largest market shares. The greater degree of concentration is the greater the possibility of non-competitive behavior existing in the market. For an efficient market, there should be sufficient number of firms (buyers and sellers). The $\mathrm{CR}_{4}$ index (the concentration ratio for the top four firms), which is given by the sum of the market shares of the largest four firms in the market as defined by Equation (2) has been the most relevant index to measure market concentration (Naldi \& Flamini, 2014).

$$
C R_{4}=\sum_{\mathrm{i}=1}^{4} S_{\mathrm{i}}
$$

Where, $C R_{4}=$ concentration ratio index, $S_{\mathrm{i}}=$ Percentage share of $\mathrm{i}^{\text {th }}$ firm $4=$ number of largest firms for which the ratio is going to be calculated.

Marketing Margin: It measures the share of the final selling price that is captured by a particular agent in the marketing chain (Mendoza, 1995). Margin determination surveys needs to be conducted parallel to channel survey. To determine the channel, one asks the questions "From whom did you buy?" and "To whom did you sell?" But according to Mendoza (1995), to obtain information concerning the margins, one has to answer the question "what price did you pay?" and "what was the selling price?" across the whole chain.

In this study, the cost and price information used to construct marketing cost and margin were gathered during field work. Computing the total gross marketing margin (TGMM) is related to the final price paid by the end buyer and is expressed as percentage as given in Equation (3) (Mendoza, 1995):

\subsubsection{Econometric Analysis}

$$
\mathrm{TGMM}=\frac{\text { Consumer price }- \text { Producer price }}{\text { Consumer price }} \times 100 \%
$$

To investigate factors affecting post-harvest losses of wheat Tobit model (Tobin, 1958) was used. As stated by Wooldridge (2012), the Tobit model expresses the observed response (y), in terms of underlying latent variable, in this case the post-harvest loss of wheat were an underlying latent variables relating to factors determining these as independent variables to measure the latent variable. The basic Tobit model formula with lower limit censoring at zero (Wooldridge, 2012):

$$
\begin{gathered}
y^{*}=\beta_{0}+x \beta+\mu, \mu / x \sim \operatorname{Normal}\left(0, \sigma^{2}\right) \\
y=\max \left(0, y^{*}\right)
\end{gathered}
$$

In Equation 5, the observed variable, $y$, equals $y^{*}$ when $y^{*} \geq 0$, but $y=0$ when $y^{*}<0$. Tobit model is one of the limited dependent variable models where there is a limit or boundary on the dependent variable and some of the observations hits this limit. The limits could be upper or lower. In this case, the values of dependent variables or wheat post-harvest loss, for a rational farmer relating to particular believed cause of loss never go beyond zero. Therefore, there is lower limit. But for some respondent producers the loss as a result of some factors hits zero. 
The maximum likelihood Tobit estimation (Tobin, 1958) was used in the analysis of factors affecting amount of post-harvest losses of wheat. For the parameter estimates to be efficient, unbiased and consistent assumptions of Classical Linear Regression (CLR) model should hold true. Hence, multicollinearity, endogeneity and heteroscedasticity detection test were performed using appropriate test statistics. The Cameron \& Trivedi's decomposition of IM-test (in Stata) was used to check for heteroscedasticity (Appendix 1) and VIF, for multi collinearity. There were no serious heteroscedasticity and multicollinearity problems.

\section{Results}

\subsection{Wheat Value Chain Actors and Their Role}

Value chain mapping enables to visualize the flow of the product from conception to consumer through various actors. Figure 2 presents the wheat value chain map in the study area comprising of complex interactions among the chain actors. These chain actors may be described being classified into two as primary and support chain actors.

\subsubsection{Primary Actors}

The primary actors include actors who were involved in moving wheat from producers to consumers. These were: the producers, who produced and sold wheat; cooperatives, who collected members' produce and sold to other traders, traders, including wholesalers, retailers, and collectors, processors, and consumers. The major functions or roles in the chain were presented to the extreme left of the map on Figure 2. These functions include input supply, production, processing and marketing, and consumption. Some of these functions or roles were performed by more than one actor, For instance, many actors deal with the marketing functions, and some actors perform more than one role, such as, the cooperatives/union were both input supplier and also engaged in output marketing.

\subsubsection{Input Suppliers}

Input suppliers were responsible to supply inputs such as: improved seed varieties, fertilizers, herbicides, insecticide, and farm implements. Producers, private vendors, primary cooperatives/union, and nongovernmental organizations were actors who were involved in wheat input supply in the study area.

\subsubsection{Producers}

Producers were the major actors who perform most of the value adding functions. The functions include: land preparation, planting, applying fertilizer, weeding, pest/disease controlling, harvesting and post-harvest handling.

\subsubsection{Collectors/Assemblers}

Collectors are part time producers or non-licensed traders who collect wheat from producers at village/town markets for the purpose of reselling to wholesalers. The collectors in some situations acted as the first link between producers and other traders. They have capital limitation. Hence, most of them receive money in advance from wholesalers of the same market or other markets to resell it back to them. Collectors use their local knowledge to bulk wheat from the surrounding area. They play important role due to their knowledge of areas of surplus wheat and cheaper prices. The trading activities of collectors include buying and assembling, repacking, sorting, transporting, and selling to wholesalers.

\subsubsection{Wholesalers}

These are licensed wheat traders who bulk and assemble wheat in their permanent store at market places and may or may not move from one market to another to buy and resale grains. Some wholesalers in the study area bought wheat directly from the producers in the market and some used to buy wheat from other district markets and brought to resale in the study area. Survey result indicated that wholesale markets were the main assembly centers for wheat in their respective surrounding areas. They had better storage, transport, and communication access than other traders. Almost all wholesalers have a warehouse in a market either self-owned or rental basis. They were located in Asella, Etaya, Borujawi, and Gonde market towns but the numbers of wholesalers in Asella market were higher than the markets in other towns. They have links with wholesalers and processors in Adama, Dire-Dawa, and Finfinnee in the central and eastern big cereal markets in Ethiopia. 


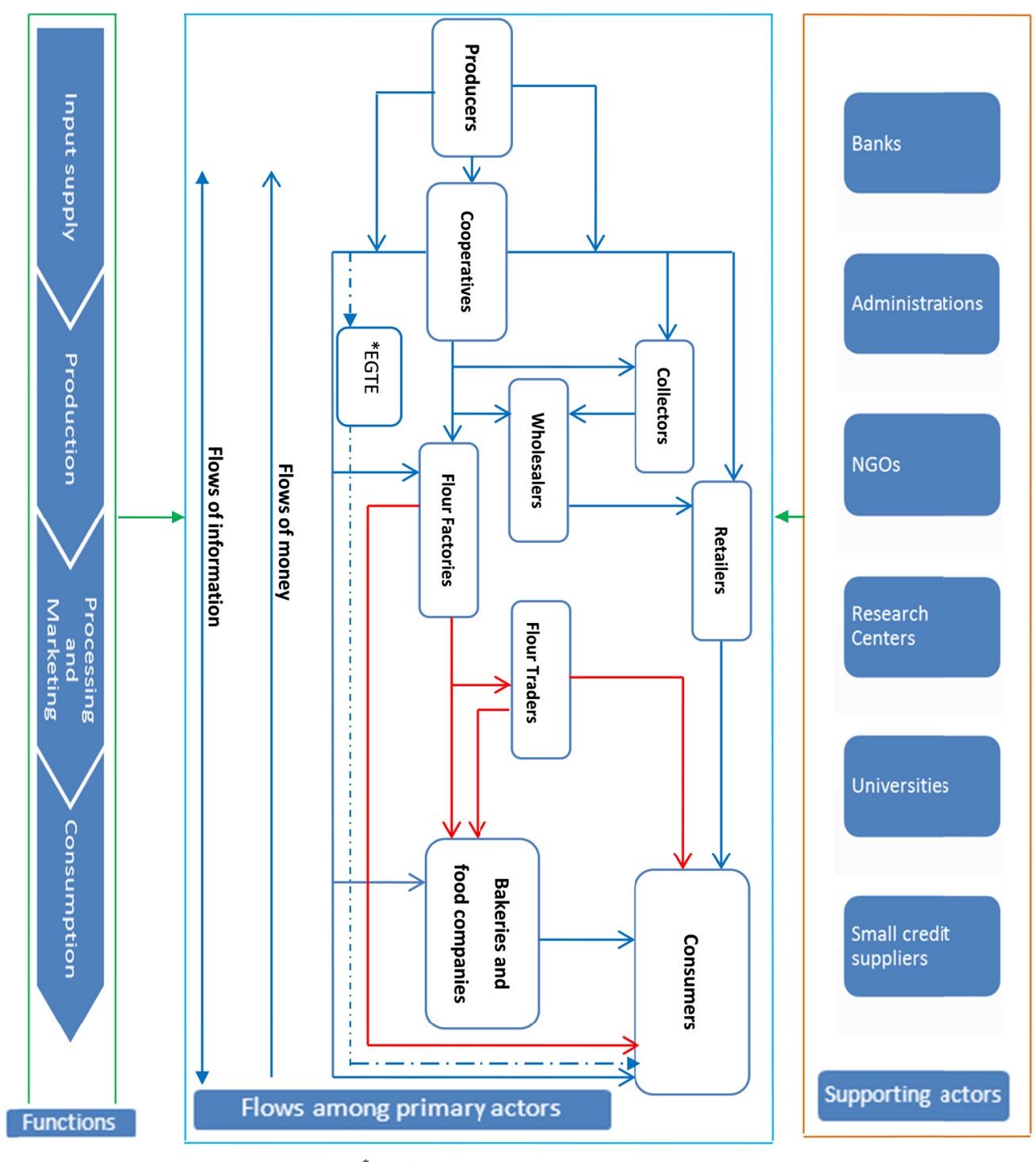

"EGTE-Ethiopian Grain Trade Enterprise

Figure 2. Simplified flowchart of wheat value chain in the study area (blue, red, and dotted lines connecting boxes on the middle diagram represent physical flow of wheat, wheat flour, and the occasional flow wheat through ETGTE, respectively)

\subsubsection{Cooperatives}

Producers' cooperatives were identified with stated objectives of serving their members in many ways such as: input distribution, providing better market access and information, expanding extension services, and extending credit services. Cooperatives in the study area, were dealing with the objective of increasing producers' bargaining power and striving to obtain benefit from economies of scale. The primary cooperatives bought wheat from members and sell to Hetosa union. Hetosa union, which was among the very strong producers' cooperative unions in Arsi zone, was participating in wheat marketing. The sampled farmer-households explained the union sold producers' produce to different processor like flour factory and food complex companies through open auctions.

\subsubsection{Retailers}

Retailers are businesses that sell the wheat to end users according to requirement and purchasing power of the buyers. The majority of wheat retailers in the study area were characterized by lack of stores at market places. They often trade wheat purchased from wholesalers, urban assemblers, and producers, and mostly they operate in producer-near markets. As the last link between producers and consumers, retailers were key actors in wheat 
value chain in the study area.

\subsubsection{Ethiopian Grain Trade Enterprise (EGTE)}

Ethiopian Grain Trade Enterprise is a state-owned enterprise that is engaged in stabilizing grain market in Ethiopia as a market leader in grain export and import. The enterprise stated its aim as "to stabilize agricultural product market and be a leader in export revenue earning". The broken line in Figure 2, indicate the flow of wheat from producer and producers' cooperatives to EGTE and from EGTE to consumers in a non-regular basis. Yet, the producers and traders in the area have claims over the enterprise. Particularly, in the two districts assessed in Arsi zone, the traders claimed that the enterprise was supplying imported wheat to flour factories at a lesser price that resulted in lesser price for their wheat. However, as the very purpose of the enterprise is to stabilize wheat market price its intervention to safeguard consumers' needs has to be hailed but it has to be in a way that shouldn't expose producers and traders in the area to losses.

\subsubsection{Wheat Consumers}

Consumers are those purchasing wheat produce for consumption. About three types of wheat consumers were identified: households, restaurants and institutions which give services such as higher education institutions, hospitals, etc. Most of institutional consumers purchase wheat from wholesalers, which had the capacity to supply sustainably based on contractual agreements.

\subsubsection{Supporting Actors}

Service providers are essential for value chain development. In this case, financial institutions (banks and small credit suppliers), institutions engaged in research and capacity building (universities, research institutes, NGOs), and administration organs were identified engaged in providing various forms of support to the primary actors.

\subsection{Level of Post-Harvest Losses and Causes of the Losses across Wheat Value Chain}

\subsubsection{Estimated Level of Post-Harvest Losses of Wheat}

Farm Level Losses: From Table 2, it can be observed that 21\% of wheat produced was lost at farm level. This was the highest loss point across the chain. It contributes about $54 \%$ of the total losses happening across the chain; hence farmer level was the loss hot-spot point. Losses during storage problems on the field $(8 \%)$ and during the harvesting activities (5.5\%) were major causes of the farm level losses. Storage problems at home and problems associated with the post-harvest activities such as cleaning, winnowing, drying, packaging, and transportation were also contributed to the wheat losses at farm level as can be seen from Table 2 .

Market Level Losses: The total post-harvest losses of wheat at collectors', wholesalers', and retailers' level were about $3 \%, 4 \%$, and $6 \%$, respectively. Problems during storage and transportation/transit were the reason behind the losses at these stages.

Processing Level Loss: The post-harvest losses of wheat at the processing level were reported at about $5 \%$ of the wheat handled during the period in the study area. 
Table 2. Estimation of post-harvest losses of wheat

\begin{tabular}{|c|c|c|}
\hline & \multicolumn{2}{|c|}{ Wheat Post-Harvest Losses } \\
\hline & $\begin{array}{l}\text { Loss (\% of total handled)-averages } \\
\text { of estimates by respondents } \\
\text { associated with causes at each stages }\end{array}$ & $\begin{array}{l}\text { Loss (\% of the total loss)-loss } \\
\text { due to the cause divided by total } \\
\text { loss along the chain }\end{array}$ \\
\hline \multicolumn{3}{|l|}{ (1) Losses at producers and producers'cooperatives } \\
\hline Harvesting & 5.5 & 14.03 \\
\hline Cleaning & 0.35 & 0.89 \\
\hline Winnowing & 0.5 & 1.28 \\
\hline Drying & 0.25 & 0.64 \\
\hline Storage at field & 8 & 20.41 \\
\hline Transport & 2.19 & 5.59 \\
\hline Packaging & 2.2 & 5.61 \\
\hline Storing at home & 2 & 5.10 \\
\hline Total loss at producers and producers' cooperatives & 20.99 & 53.56 \\
\hline \multicolumn{3}{|l|}{ (2) Collector level losses } \\
\hline Storage & 0 & 0 \\
\hline Transit & 3.4 & 8.68 \\
\hline Total losses at collector level & 3.4 & 8.68 \\
\hline \multicolumn{3}{|l|}{ (3) Wholesale level losses } \\
\hline Storage & 2.7 & 6.89 \\
\hline Transit & 1.25 & 3.19 \\
\hline Total losses at wholesale level & 3.95 & 10.08 \\
\hline \multicolumn{3}{|l|}{ (4) Retail level losses } \\
\hline Storage & 2.6 & 6.63 \\
\hline Transit & 1.7 & 4.34 \\
\hline Handling & 1.3 & 3.32 \\
\hline Total loss at retail level & 5.6 & 14.29 \\
\hline \multicolumn{3}{|l|}{ (5) Processor level losses } \\
\hline Storage & 1.5 & 3.83 \\
\hline Transit & 2.4 & 6.12 \\
\hline Wheat scattering & 1.35 & 3.44 \\
\hline Total losses at processor level & 5.25 & 13.40 \\
\hline * Total post-harvest losses from farm to processor & 39.19 & 100 \\
\hline
\end{tabular}

Note. ${ }^{*}$ Simple arithmetic sum of the percentage losses at each stage; it does not mean that $39 \%$ of production was lost.

\subsubsection{Econometric Analysis of Factors Affecting Post-Harvest Losses of Wheat}

Several variables (see Table 3 ) were imagined to influence the level of post-harvest loss (Kg per quintal of wheat loss in the whole sampled producers) of wheat by sampled producers. Tobit model was employed to assess these factors and the result was presented in Table 3. Attempts were made to include all theoretically important factors in the Tobit model which could be measured quantitatively or as dummy variable (e.g. good versus bad). 
Table 3. Tobit model outputs of factor affecting post-harvest loss of wheat

\begin{tabular}{|c|c|c|c|c|}
\hline \multirow[b]{2}{*}{ Variables } & \multicolumn{2}{|c|}{ Coefficients } & \multicolumn{2}{|c|}{ Marginal effects } \\
\hline & Coefficient & $\begin{array}{l}\text { Standard } \\
\text { errors }\end{array}$ & $\begin{array}{l}\text { Change among the whole } \\
\qquad \frac{\partial E\left(Y_{i}\right)}{\partial x_{i}}\end{array}$ & $\begin{array}{l}\text { Change in probability } \\
\qquad \frac{\partial \mathrm{F}(\mathrm{Z})}{\partial \mathbf{x}_{\mathrm{i}}}=\mathrm{f}(\mathrm{z}) \frac{\boldsymbol{\beta}}{\sigma}\end{array}$ \\
\hline Sex of household head (M) & $-0.12 * *$ & 0.043 & 0.009 & -0.0124 \\
\hline Age of household head & -0.001 & 0.001 & 0.504 & -0.0012 \\
\hline Active-age family size & $-0.013 * *$ & 0.005 & 0.032 & -0.0132 \\
\hline Education status of household head & 0.031 & 0.035 & 0.64 & 0.0314 \\
\hline Volume of production & $5.18 * * *$ & 0.44 & 0.91 & 0.009 \\
\hline Livestock holding & $-2.88 * *$ & 2.68 & -4.56 & -.05 \\
\hline Wheat Farming experiences & $-4.31 *$ & 0.25 & -0.33 & -0.003 \\
\hline Distance to nearest market & $1.255^{* *}$ & 6.22 & 9.72 & 0.1260 \\
\hline Access to credit & -4.68 & 6.22 & -3.63 & -0.03 \\
\hline Type of seed used & 0.76 & 6.14 & 0.59 & 0.0006 \\
\hline Weather conditions $(\mathrm{G})$ & $-1.36 * * *$ & 0.0027 & 0.000 & -0.0364 \\
\hline Conditions during Threshing process $(\mathrm{G})$ & $-0.39 * *$ & 0.022 & 0.080 & -0.3941 \\
\hline Transportations' conditions (G) & $-0.035^{* *}$ & 0.044 & 0.404 & -0.0553 \\
\hline Storage facility on field and at home & $-4.06 * * *$ & 0.005 & 0.000 & -0.0465 \\
\hline Constant & 36.4 & 29.18 & & \\
\hline
\end{tabular}

Note. ${ }^{* * *},{ }^{* *}$, and $*$ are statistically significant at $1 \%, 5 \%$ and $10 \%$ significance level; M: male; G: good.

Among the variables included in the analysis three variables: volume of production, storage facility on filed and at home, and weather conditions significantly contributed to wheat losses in the area at $1 \%$ statistical significance. According to the result on Table 3, an increase in a quintal of wheat production resulted in an increase in post-harvest losses of $5.18 \mathrm{~kg}$ or $5.18 \%$ post-harvest losses. The existence of good storage facility could save $4.06 \mathrm{Kgs}$ of wheat per quintal, and occurrence of bad weather conditions particularly rain during harvesting time contributed to $1.36 \mathrm{Kgs}$ of wheat losses per quintal. At $5 \%$ statistical significance, many of the variables appeared contributing to post-harvest losses of wheat in the area. These include sex of household head, active-age household family size, livestock holding, and distance to the nearest market place, conditions during threshing process, and transportations conditions. According to the result on Table 3, being female-headed household contributed to $0.12 \mathrm{Kgs}$ of wheat post-harvest losses per quintal, an increase of family size by one active-aged person could reduce wheat post-harvest losses by $0.013 \mathrm{Kgs}$ per quintal. Similarly, the number of livestock owned by the producers was found negatively related to the level of wheat post-harvest losses that an increase in one unit of livestock holding could decrease wheat post-harvest losses by $2.88 \mathrm{Kgs}$ per quintal. Distance to the nearest market place has an effect on the level of wheat post-harvest losses at $5 \%$ significance level that a $\mathrm{km}$ increase in the distance to the nearest market place has resulted in an increase in wheat post-harvest losses by $1.26 \mathrm{Kgs}$ per quintal.

\subsection{Value Share among Wheat Value Chain Actors and Market Performance}

\subsubsection{Value Share among Wheat Market Actors}

By taking into consideration the associated marketing costs for key wheat value chain actors, and estimating the marketing and profit margins, the marketing performance of the wheat markets were analyzed. Table 4 indicated different types of marketing cost related to the transaction of wheat by producers, collectors, wholesalers, retailers and processors, and the benefit share of each chain actors. Each of the wheat value chain actors adds value to the product as the product passes from one actor to another. In a way, the actors add value to the wheat through improving the grade by sorting, cleaning or create space and time utility. Compared to producers, traders' (collectors, wholesalers, and retailers) value addition share was not as significant. Producers involved in land preparation, planting, input application, weeding, harvesting, and transporting the produce to the market place, which could be imagined as more than $50 \%$ of the value added to the wheat. However, their share both in marketing margin and profit margin were below 50\%, i.e., $29 \%$ in market margin and $16 \%$ in profit margin. The traders who involved only in a limited value addition practices were getting nearly the same share in profit margin with the producers. Collectors', wholesalers', and retailors' share in profit margin were $13 \%, 14 \%$, and $6 \%$ 
respectively, which sums to about $33 \%$ of the profit margin. That means by simply buying from the producers and selling to next chain actors, with very few additional value addition tasks such as sorting, storage, and transporting, traders took $33 \%$ of the total profit margin. While producers, doing all the work of producing wheat and bearing the associated risks, took only $16 \%$ of the profit margin. More importantly, the highest profit share goes to processors, where $51 \%$ of the profit margin accrues. This indicated that how much processing-based value addition is important in wheat chain studied. Though from the cost list the processors seemed inefficient, the high price of wheat flour resulted in high share of profit margin for the processors. As can be seen from Table 4 , the flour price (selling price at the processor) was more than the wheat retail price by $35 \%$. The majority of the processors in the area were engaged in converting the wheat to flour and selling the flour to bakeries and food companies. Few of them, have engaged not only in selling flour but also have bakeries as side business. The disproportionate share of benefits is the reflection of power relationship among actors. The price change from producers' price to consumers' price is $33 \%$ at retail price and $80 \%$ at processor (flour) price.

Table 4. Wheat cost structure and profit shares among the actors

\begin{tabular}{|c|c|c|c|c|c|c|}
\hline Items(birr/quintal) & Producer & Collector & Wholesalers & Retailers & *Processors & Sum \\
\hline Purchase price & _- & 750 & 850 & 900 & 950 & 3440 \\
\hline Production cost & 450 & - & _- & - & - & 450 \\
\hline Production or purchase cost (a) & 450 & 750 & 850 & 900 & 950 & 3890 \\
\hline \multicolumn{7}{|l|}{ Marketing costs } \\
\hline Labour & 30 & 5 & 5 & 4 & 20 & 64 \\
\hline Transport & 20 & 10 & 10.5 & 2 & 25 & 74.5 \\
\hline Overhead cost & 4 & 3 & 2 & 1 & 10 & 20 \\
\hline Packaging materials & 5 & 5 & 5 & 5 & 10 & 30 \\
\hline Tax & - & - & 4 & 3 & 7.5 & 17.5 \\
\hline Total marketing cost (b) & 59 & 23 & 26.5 & 15 & 72.5 & 206 \\
\hline$* *$ Post-harvest loss as a cost (c) & 157.50 & 24.45 & 36.6 & 56.7 & 67.5 & 342.75 \\
\hline Total cost/TC/(a+b+c) & 666.50 & 782.45 & 913.10 & 971.7 & 1090 & 4438.75 \\
\hline Selling price (SP) & 750 & 850 & 985 & 1000 & 1350 & 4775 \\
\hline Market margin(SP-a) & 300 & 100 & 135 & 100 & 400 & 1035 \\
\hline Share in market margin & 0.29 & 0.10 & 0.13 & 0.10 & 0.39 & 1 \\
\hline Profit margin (SP-TC) & 83.50 & 67.55 & 71.90 & 28.30 & 260 & 511.25 \\
\hline Share in profit margin & 0.16 & 0.13 & 0.14 & 0.06 & 0.51 & 1 \\
\hline Profit Margin without considering post-harvest loss as cost & 241 & 92 & 108.5 & 85.5 & 327.5 & 854.5 \\
\hline Share in profit margin without considering post-harvest loss as cost & 0.28 & 0.10 & 0.13 & 0.10 & 0.39 & 1 \\
\hline
\end{tabular}

Note. ${ }^{*}$ Just for simplicity, a quintal of wheat is assumed to be converted to a quintal of wheat flour; ${ }^{* *}$ Level of post-harvest loss was estimated at each stage of the value chain (see Section 3.2.1).

The percentage was converted to $\mathrm{Kg}$ per quintal as quintal is equal with $100 \mathrm{Kgs}$. Therefore, a $21 \%$ loss at producers' stage means $21 \mathrm{Kgs}$ per quintal is lost. This means the farmer lost 157.50 birr per $100 \mathrm{Kgs}$ or quintal of wheat produced as the selling price at the farmer stage was 750 per quintal or 7.50 birr per Kg. In similar manner, the post-harvest loss was converted to cost/lost revenue for all chain actors.

Looking on the last two rows of Table 4, shows that one of the cost item that made producers profit margin at small amount is the level of high post-harvest loss at this stage, without considering post-harvest loss as a cost farmers' profit margin grows to $28 \%$, which may be still considered as small share compared to the imagined proportion of value added by the producers. However, this is important information that shows how the producers were suffering from post-harvest losses. Note that the price and cost information in Table 4 were averages from all assessed markets for each category and are not constant throughout the year. Furthermore, whereas the costs for other chain actors were directly obtained from the actors on a per quintal bases, the production cost for producers were calculated by relating the average resources applied to a hector of land and average production per hector for the sampled producers.

\subsubsection{Structure of the Wheat Market}

In this study, the structure of the wheat market is explained using the following indicators: market concentration, 
the degree of clearness (market information), and entry conditions.

Table 5. Market concentration ratio for Etaya, Asala, Adama, and Finfinnee markets

\begin{tabular}{|c|c|c|c|c|c|c|c|c|}
\hline \multirow{2}{*}{$\begin{array}{l}\text { Traders by } \\
\text { volume of sales }\end{array}$} & \multicolumn{2}{|c|}{ Etaya market } & \multicolumn{2}{|c|}{ Asala market } & \multicolumn{2}{|c|}{ Adama market } & \multicolumn{2}{|c|}{$\begin{array}{c}\text { Finfinnee/Addis Ababa/ } \\
\text { market }\end{array}$} \\
\hline & $\begin{array}{l}\text { Volume } \\
\text { (in qt) }\end{array}$ & $\begin{array}{l}\text { Market share } \\
(\%)\end{array}$ & $\begin{array}{l}\text { Volume } \\
\text { (in qt) }\end{array}$ & $\begin{array}{l}\text { Market share } \\
(\%)\end{array}$ & $\begin{array}{l}\text { Volume } \\
\text { (in qt) }\end{array}$ & $\begin{array}{l}\text { Market share } \\
(\%)\end{array}$ & $\begin{array}{l}\text { Volume } \\
\text { (in qt) }\end{array}$ & $\begin{array}{l}\text { Market share } \\
(\%)\end{array}$ \\
\hline Trader 1 & 2500 & 8 & 8365 & 17.5 & 755000 & 19.2 & 597600 & 14.5 \\
\hline Trader 2 & 2300 & 7.3 & 3800 & 8 & 378000 & 9.6 & 490820 & 11.9 \\
\hline Trader 3 & 2000 & 6.4 & 3375 & 7 & 295000 & 7.5 & 398000 & 9.7 \\
\hline Trader 4 & 1600 & 5.1 & 2500 & 5.2 & 198058 & 5.0 & 300579 & 7.3 \\
\hline Trader 5 & 1300 & 4.2 & 2300 & 4.8 & 166163 & 4.2 & 278900 & 6.8 \\
\hline Trader 6 & 1200 & 3.88 & 2100 & 4.4 & 24520 & 0.6 & 250000 & 6.1 \\
\hline All other traders & 20262 & 65 & 25521 & 53 & 2107977 & 53.7 & 1800538 & 43.7 \\
\hline Total & 31162 & 100 & 47961 & 100 & 3924718 & 100 & 4116437 & \\
\hline
\end{tabular}

Degree of Market Concentration: The information for the total wheat traded in the markets and estimated prices and amount of wheat traded weekly and yearly were collected from the bureau of agriculture and rural development and district finance bureau for Etaya and Asala markets. In Adama and Finfinnee markets, though the lists of the traders were collected from the trade and industry authorities of the two cities, their annual sale was not registered. Therefore, in order to calculate the $\mathrm{CR}_{4}$ for the latter two markets the information about their annual sale was collected from themselves by phone and in person interviews. The degree of market concentration was estimated for licensed wheat traders in Etaya, Asella, Adama, and Finfinnee markets using the four firm concentration ratios and the result were presented in Table 5. For the major wheat markets assessed, the $\mathrm{CR}_{4}$ concentration ratio was computed. From data in Tables 5, the level of market concentrations computed as $\left(\mathrm{CR}_{4}=\mathrm{S}_{1}+\mathrm{S}_{2}+\mathrm{S}_{3}+\mathrm{S}_{4}\right)$ for Etaya, Asala, Adama, and Finfinnee markets were 26.8\%, 37.7\%, 41.4\%, and $42.9 \%$, respectively.

Degree of Clearness (Market Information): According to the survey result (Table 6), sample traders obtained information related to wheat price, supply, and demand conditions through other traders, brokers, telephone, personal observation, price ticker board, and mass media like radio, television, and newspapers.

Table 6. Market information and its source for traders

\begin{tabular}{lllll}
\hline Variables & Total (\%) & Wholesaler (\%) & Collector (\%) & Retailer (\%) \\
\hline Source Information & & & & \\
Other traders (yes) & 97.65 & 100 & 87.50 & 100 \\
Personal observation (yes) & 82.35 & 77.78 & 87.50 & 82.35 \\
Broker (yes) & 3.53 & 6.67 & 0 & 0 \\
Price tickers (yes) & 37.65 & 40 & 18.75 & 45.83 \\
Radio (yes) & 74.12 & 62.22 & 87.50 & 87.50 \\
Newspaper (yes) & 12.94 & 8.89 & 12.50 & 20.83 \\
Television (yes) & $\mathbf{8 3 . 5 3}$ & $\mathbf{9 7 . 7 8}$ & $\mathbf{1 8 . 7 5}$ & $\mathbf{1 0 0}$ \\
\hline
\end{tabular}

Barrier to Entry: The barriers to entry into the grain market reflect the competitive relationships between existing traders and potential entrants. If the barriers to entry are low, new traders can easily enter into grain markets and compete with established traders. Trade barriers have often laid the groundwork for market imperfection. The major barriers to entry into wheat trade in the study areas, as presented in Table 7, included lack of working capital, bureaucratic licensing procedures and competitions. 
Table 7. Barriers to wheat market entry

\begin{tabular}{ll}
\hline Barriers & Respondent from all samples (\%) \\
\hline Trading licenses (yes) & 45 \\
Lack of capital (yes) & 90 \\
Competition with others (yes) & 60 \\
\hline
\end{tabular}

Licensing: According to the survey result in Table 7, 45\% of traders having wheat-trade license and residing in the town reported that it is very bureaucratic to get wheat trade license, as they are required to fulfill a number of criteria to be verified by the trade licensing office. The traders noted getting the appropriate officers on time was their major problem beside the fulfillment of the criteria. As a result, many traders particularly the retailers and collectors were non-licensed traders. In sum, it was noted that the bureaucratic licensing procedure creates a barrier to entry for officially permitted traders but created many non-licensed wheat traders in the area.

Lack of Capital: In the survey (Table 7), about $90 \%$ of the sample traders respond that major problem to enter into wheat market was lack of enough capital. Although the working capital required was reported to vary depending upon the price level and quantity of grain to be purchased, high amount of initial working capital was required to compete with wholesalers, collectors, and cooperatives. To enter into the market more capital is needed because they have to purchase more wheat and they have to pay cash on hand at the time of purchase. In addition, high capital is required for warehouse construction or rental for adequate storage facilities at the market places. The traders strongly noted that capital requirement discourage entry into wheat trading. They noted their problem was more complicated as access to formal financial sources/credits to expand their trading activities was limited due to the credit procedures by the financial institutions.

High Competition: Competition among licensed and non-licensed traders, competition with marketing cooperatives and organized large wholesalers was also reported as barrier to entry for young businesses to the wheat trade in the area. This was also related to lack of enough capital to cope-up with the competition. As those having enough capital buy large amount of wheat during harvesting season with low price and sell it the whole year. But those with no capital have no chance to use this opportunity to buy large quantity during cheap price hence were losers in the competition.

\subsubsection{Wheat Market Conduct}

Market conduct refers to the patterns of behavior that firms follow in adopting or adjusting to the markets in which they sell or buy. In this study, conduct of the wheat market was analyzed in terms of price setting, purchasing, and selling strategies.

Producer's Price Setting Strategy: According to the survey result (Table 8), about $82 \%$ of sample farmer respondents said that, market price was set by buyers and $14.7 \%$ respondents said that, price was set by the market through the interactions between supply and demand by negotiation. Only 3.3\% of farmer respondents said that the selling price of their produce was set by themselves.

Table 8. Producer price setting strategy

\begin{tabular}{lllll}
\hline Strategy & Responsible & All samples (\%) & Hetosa (\%) & Tiyo (\%) \\
\hline Who set price? & Buyer & 82 & 85 & 80 \\
& Negotiation or supply and demand & 14.66 & 83.35 & 6.67 \\
& Producers themselves & 3.33 & 5 & 2.22 \\
\hline
\end{tabular}

Trader's Purchasing and Selling Strategy: The critical period for wheat purchase was immediately after harvesting during the months of November to January. Wholesalers primarily purchase from producers and also use collectors as second source to purchase. All traders in the local market did not report the use of brokers for purchasing wheat, but in Adama and Finfinnee markets, some traders noted they were working with brokers to contact with wheat suppliers who bring wheat from rural markets. As the result presented in Table 9 indicated, traders in the area used a variety of criteria to attract their suppliers, $81.2 \%$ of trader respondent said that, they attract their suppliers by fair scale-weighing, $8.24 \%$ by giving better price relative to others, $7.06 \%$ by giving credit, and the rest (3.53\%) by visiting their suppliers. It was startling for the researchers that how standardized weight measurement can service to attract customers, as a $\mathrm{Kg}$ of wheat is a $\mathrm{Kg}$ of wheat wherever it is measured. However, the questions asked to the producers on this issue showed that some traders were doing some kind 
alteration to the measurement machine to reduce the real weight. We have asked the authorities and they confirmed the same and they said they do inspections occasionally to control the problem. On the other hand, majority of the traders $88 \%$ of respondent traders said they used quality as a means of attracting their buyers. They defined quality of wheat as the wheat with good looking seed, free from foreign materials, well dried, and preferred wheat varieties by their customers.

Table 9. Traders' supplier and buyer attraction strategies

\begin{tabular}{llllll}
\hline Variables & & All samples (\%) & Wholesalers (\%) & Collectors (\%) & Retailers (\%) \\
\hline How do you attract suppliers? & Better price & 8.2 & 15.56 & 0 & 0 \\
& Fair scale & 81.2 & 68.89 & 87.50 & 100 \\
& Visiting them & 3.5 & 2.22 & 12.50 & 0 \\
& Giving credit & 7.1 & 13.33 & 0 & 0 \\
\hline How do you attract buyers? & Low price & 7.1 & 4.44 & 0 & 0 \\
& Fair scale & 2.4 & 4.44 & 0 & 4.44 \\
& Visiting them & 0 & 0 & 0 & 2.33 \\
& Giving credit & 2.4 & 4.44 & 100 & 83.33 \\
\hline
\end{tabular}

\subsection{Supply Chain Management in the Explored Wheat Chain}

In order to understand the situation of the supply chain management aspects in the assessed wheat value chain, many explorative questions were asked to the primary chain actors and the situation was analyzed in conjunction with secondary data sources. The results from the questions were presented in Figure 3 and Appendix 2. Figure 3 showed how the major wheat supply chain actors interact in the chain. These chain actors were asked how they usually performed their business with the upper-stream suppliers and down-stream buyers. Accordingly, the whole producers and retailers responded that their only means of doing business with their transaction partners were spot-market agreement. On the other hand, information from collectors depicted that all of the collectors had neither oral contract nor written contract with the suppliers or the producers but $63 \%$ and $16 \%$, had oral and written contractual agreement with their buyers, respectively. Wholesalers and processors relatively had establishing formal relationships with their transaction partners. That is, $36 \%$ and $31 \%$ of wholesales responded they had oral contracts with their suppliers and buyers, respectively; $18 \%$ and $12 \%$ of them had written contracts with suppliers and buyers, respectively. Similarly, $42 \%$ and $9 \%$ of the processors had oral agreement with their suppliers and buyers while $23 \%$ and $27 \%$ of them had written contract agreement with their suppliers and buyers, respectively.

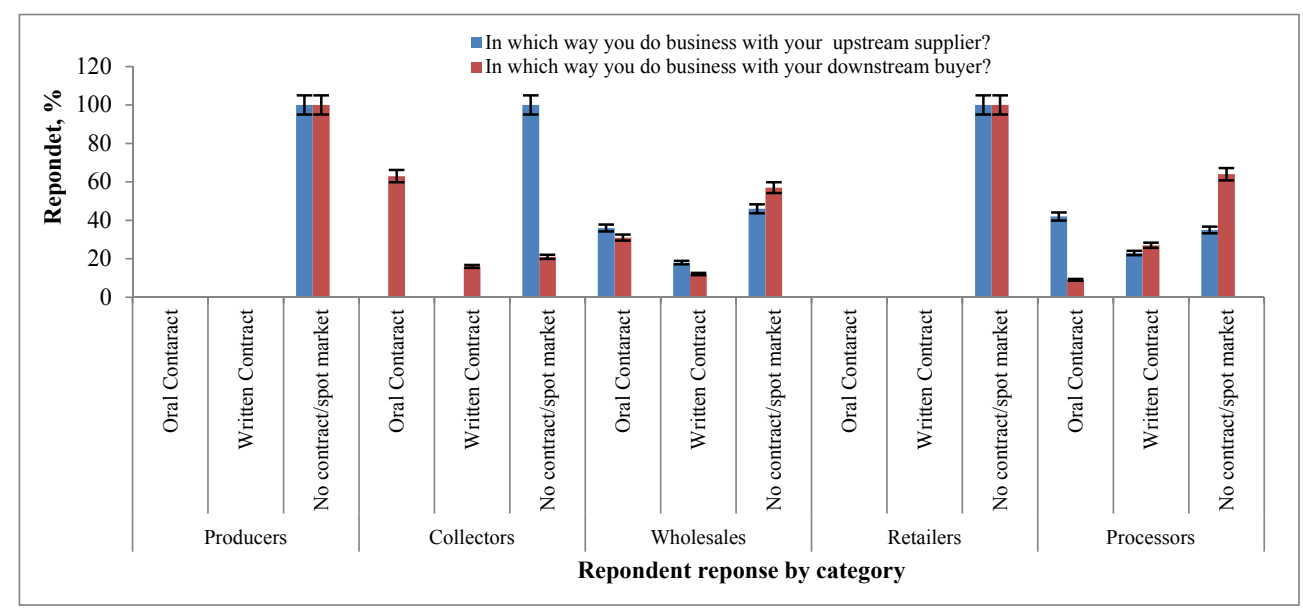

Figure 3. mode of agreement with business partner in the wheat chain (5\% error bar)

Result presented in Appendix 2 presented more detail explorative results about the nature of the wheat supply 
chain assessed. According to the result, it can be argued that the wheat chain assessed was characterized by disintegrated chain where businesses were self-oriented and mutualism has never developed. As can be read from Appendix 2, the majority stated that it was difficult to get reliable information about the whole wheat market from local to central markets, they had difficulty of getting proper business partner (customer) with whom to transact on a sustainable manner, and also difficult to agree on conditions of long-standing contracts. Further assessment on the result presented on Appendix 2 showed that majority of the respondents' relationships with their major business partner were not significantly different from the relationships with other ordinary customers. Indicators for this include: for most of the respondents there was no difference in frequency of transaction between the major partner and the others, those having contracts reported they usually betray the contract easily, there were no long-time established cooperation among the business with their major partners, trust was not well developed, there were no established and dependable logistics system that could ensure the product supply among the business partners, and so on (see Appendix 2).

\section{Discussions}

\subsection{The Wheat Value Chain in Ethiopia}

Wheat is one of the most important cereals in Ethiopia. Its contribution to food security of the country is of paramount. According to Kasa et al. (2015), wheat and wheat products contributed to about $14 \%$ of the total caloric intake in Ethiopia, which made wheat the second-most important food, behind maize (19\%) and ahead of teff, sorghum, and enset (10-12\% each). It ranks fourth after teff, maize and sorghum, in area coverage and third in total production (CSA, 2012/13). According to CSA (2012/13), wheat contributes to about $15 \%$ of total annual grain productions in Ethiopia. Wheat consumption in Ethiopia also showed increasing trend overtime. Within a decade between 2002 and 2012 the total wheat consumption in Ethiopia increased by more than $65 \%$ (Kathryn Bergh et al., 2012). Therefore, the high demand for wheat products which was explained by the increasing trend in wheat production and consumption in Ethiopia created an opportunity for wheat value chain development in the country. Beside the national demand which was increasing in high rate, Ethiopia's geographic position in Sub-Saharan African countries and its wheat production potential compared to others in the region created another opportunity for Ethiopian wheat value chain to integrate to global food chains. Demeke and Di Marcantonio (2013) indicated Ethiopia is the second largest wheat producer in Sub-Saharan Africa, after South Africa. However, from the present study and review of similar reports Ethiopia's wheat value chain has not yet developed to the level required. If the wheat value chain is well-established it stimulates increasing local production. Presently, the local production has not yet satisfied local market demand. Thus, Ethiopia remains the net wheat importer (Kasa et al., 2015). From the assessment made by this study the following major challenges that policy makers need to tackle were identified, if Ethiopia has to benefit from developing wheat value chains.

The Disproportionate Share of Benefits: As the result under Section 3.3.1 presented, the assessed wheat value chain was characterized by unfair share of benefit among the chain actors. The producers who were in a position of adding the highest portion of value to the wheat received only $16 \%$ of the profit margin. The traders (collectors, wholesalers, and retailers) jointly shared $33 \%$ of the profit margin and the remaining $51 \%$ of the profit margin goes to processors. In the new business arena, the concepts of integration and collaboration among the business partners of the food supply chains have got high importance. Business today are in the era of inter-network competition hence self-standing business competition does not give much sense (Lambert \& Cooper, 2000). The 'resource or market based competitiveness', which argues business success as a function of access to crucial resources or as a result of existing market power is now considered as a traditional view and was replaced by 'relational view'. In the 'relational view', business organizations that form smart partnerships, strategic alliances, and efficiently coordinate the value chains will have competitive advantage Emerson and Rowarth (2009a) as cited in (Junqueira, 2010). Critical to the relations view is the quality of relationships among the business partners in the food chains. The partners need to develop trust on each other and a trust on the idea that overall profitability of the chain will lead to individual firms' profitability. Where majority of the benefit obtained in the process is going only to few actors in the chains, as in this case study, it is rarely possible that trusting food value chain can be developed. Hence, it needs to design and implement a policy for fair benefit sharing among all chain actors in the assessed wheat value chain. There should be a systematic support to the poor, particularly to the producers in order they get share of the benefit in proportion to the value they contributed. That will improve benefits not only to the producers but also to the whole chain actors by stimulating higher production and efficient and effective marketing along the wheat value chain.

The Market Structure, Conduct, and Performance (S-C-P): The S-C-P is one of the market performance measures. The general idea of S-C-P model is that the structure of a market such as the nature of competition explained by the number and relative size of the competitors determines how the market behaves (market 
conduct), and the market conduct (behavior), in turn, affects the market outcome or performance such as quantities sold and prices. In this study, the market structure was assessed by using the four firm concentration indexes. According to Naldi and Flamini (2014), the use of $\mathrm{CR}_{4}$ index has two pitfalls. First, it does not show the power distribution among the top four firms, i.e., "a market in which each of the four largest firms has $20 \%$ of the market share has the same $\mathrm{CR}_{4}$ value as another market in which the top four firms have shares of $55 \%, 20 \%$, $4 \%$, and $1 \%$, respectively, i.e., $80 \%$ on the overall." Second, it does not clearly show the monopoly or oligopoly risks derived from mergers between the top four firms. Regardless of this pitfall, $\mathrm{CR}_{4}$ is widely used measure of market competition. The standard interpretation of the index used in this study was the one given by Naldi and Flamini, (2014), i.e., $\mathrm{CR}_{4}$ of $0,0<\mathrm{CR}_{4}<40 \%, 40 \%<\mathrm{CR}_{4}<60 \%$, and $>60 \%$ are categorized as perfect competition, monopolistic competition, loose oligopoly, and tight oligopoly, respectively. The result under Section 3.3.2 indicated that in the markets near to the producers (Etay \& Asala) the concentration ratio $\left(\mathrm{CR}_{4}\right)$ was less than $40 \%$ showing that there are fair numbers of traders resulting in fair competition (monopolistic competition) among them. As we move up to the central market, the four firm concentrations ratio $\left(\mathrm{CR}_{4}\right)$ rises above $40 \%$ which shows that the central wheat markets were a bit less competitive (loose oligopoly). This could be attributable to the fact that traders in central markets are more specialized focusing on grain trade as their major business but their number may be limited due to the large capital requirement for operations at central markets and licensing bureaucracy. However, at source market, less capital requirement, the existence of non-licensed traders, and the fact that the producers themselves can directly sell to consumers created lesser control of the market by few major traders. However, overall the whole wheat markets assessed across the chain were neither perfectly competitive nor tight oligopoly; they were just between monopolistic competition and loose oligopoly.

Post-Harvest Losses: When issue of food security is discussed, three important challenges that may come to scholars' mind include: challenge of meeting future food demand, the current food security problem, and food loss and waste. Challenge number one, meeting future food demand, is concerned with all parts of the world. It is global concern to feed its ever-increasing population that is expected to exceed 9 billion by 2050 (Godfray et al., 2010). Tomlinson (2013) discussed the fact that increasing food production by $70-100 \%$ was becoming a universal agreement among many scholars in order to feed global people by 2050 . The author noted the idea became universal agreement among the scholars wrongly by noting the idea was not intended and even if it was intended, it failed to address problems of climate change, diet-related problems, and to reduce absolute levels of hunger. Regardless, the author believed on the importance of increasing food production and the challenge of feeding 9 billion people by 2050, except for statistical exaggerations noting $70-100 \%$ increase in food production. The second challenge, the current food security problem, is more concerned with some part of the world. Currently, about one in nine (11\%) of the world's population goes to bed hungry each night (WFP, 2014). The intensity of food insecurity varies between global regions. Sub-Saharan African countries are among the most affected regions and this is projected to continue to be a very vulnerable region during the coming decade (Rosen et al., 2014). The third challenge is food loss and waste exacerbating the first two challenges. That is significant proportion of (estimates vary between 25\%-40\%) global food produced for human consumption was lost resulting in not only the losses of the food but also the losses of the scarce resources used to produce the food and also exposing the globe to additional economic and environmental costs to discard the lost food (Kummu et al., 2012; Godfray et al., 2010; Parfitt et al., 2010; Hodges et al., 2011; Rembold et al., 2011). In this study, significant portion of the wheat produced was lost across the supply chain. Although, it may not be appropriate to believe in the estimated figures exactly as reported due to the subjectivity problem associated with the questionnaire based loss estimation methods, this study noted the farmer stage of the wheat chain needs more attention as loss-hot-spot point. The factors assessment showed that except for weather conditions, the factors are controllable and support to the producers could alleviate the wheat loss problems. Some of the factors related to the personal characteristics of the household heads such as sex of the household head, active aged family size, and numbers of livestock holdings were identified influencing post-harvest losses. This may be related to the time or man-hour availability for harvesting the wheat. Female headed households tend to be more susceptible to losses due to the fact that they have less man-hour compared to male counterparts as a result of their additional duties at home and households with more livestock holdings have financial capacity to buy labor for harvesting, hence less vulnerable to losses, and more active aged family size means more man-hour for on-time harvesting resulting in lesser losses. Other factors influencing post-harvest losses of wheat in the area are related to logistics and infrastructure which include: storage facilities, distance to the nearest market place, conditions of the threshing process, and transportation conditions. These are expected results as in many studies (Parfitt et al., 2010; Harris \& Lindblad, 1978; Hodges et al., 2011), poor logistics and infrastructure was contributing to high post-harvest losses. Therefore, this urges all stakeholders including the government to invest on public goods 
such as roads, establishment of market places near the producers, and enabling the chain actors for developing effective logistics system in the chain.

\subsection{Supply Chain Management in the Wheat Value Chain}

When markets powers are controlled by few intermediate food value chain actors, traders and/or processors, high food consumer prices, which could be unaffordable for low-income groups in urban areas is expected. Moreover, it can hamper producers' motivation and capacity to improve production through investments on production innovations. This in turn has negative impact on viability of the value chain and all of the chain actors including those with temporary market power. Therefore, for agricultural value chain to be viable in the long-run the market power needs to be distributed. This can be possible by establishing supply chain management system through the formation of partnerships and trust among the legally separate chain actors.

The problems identified in this wheat value chain such as lack of transparency and trust among the chain actors, the disproportionate share of benefit, and high losses of wheat in the chain can be alleviated through the implementation of supply chain management system. On the other hand, solving these problems has positive impact for effectiveness of the wheat supply chain management. Many scholarly works (Vorst et al., 1998; Van der Vorst et al., 2007; Stank et al., 1999; Power, 2005; Mena \& Stevens, 2010) identified the role of food supply chain management as a means of developing trustful partnerships in foods chains and the role of trust for effectiveness of supply chain management. A well-established supply chain management system has potential to improve benefit share among the chain actors and overall market performances (Hellin et al., 2009; Taylor, 2005). Similarly, some authors (Kummu et al., 2012; Lipinski et al., 2013) noted the role of supply chain management in reducing food losses in food value chains. Developing a dependable logistics system (transportation, warehousing, money and information exchange, etc.) can be possible in effectively implemented food supply chain management system and doing so can solve many of the problems identified in the studied wheat value chain.

\section{Conclusions and Recommendations}

In this study, the wheat value chain from one of the highest wheat producing area in Ethiopia (Arsi zone of Oromia region) all the way to central markets in Finfinnee/Addis Ababa was assessed focusing on market performance, post-harvest losses and the potential of supply chain management to improve the chain.

The results showed diversified actors in the wheat chain contributing to the movement of wheat from producers to consumers. These actors were discussed being categorized into two as primary actors and secondary actors. The primary actors included the producers, their cooperatives, traders (collectors, wholesalers, and retailers), EGTE, and processors.

High post-harvest losses of wheat were identified in the assessed wheat value chain. With $21 \%$ postharvest-loss or $54 \%$ of the total loss happening at the producers' stage, producers' stage was identified as loss-hot-spot point in the wheat chain. Volume of production, storage facility on filed and at home, and weather conditions significantly contributed to wheat losses in the area at $1 \%$ statistical significance. An increase in a quintal of wheat production, bad storage facilities and bad weather conditions resulted in an increase in post-harvest losses of 5.18, 4.06 and $1.36 \mathrm{Kgs}$ of wheat losses per quintal, respectively. At 5\% statistical significance, sex of household head, active-age household family size, livestock holding, and distance to the nearest market place, conditions during threshing process, and transportations conditions appeared contributing to post-harvest losses.

The assessed wheat value chain was characterized by unfair share of benefit among the chain actors. The producers who were in a position of adding the highest portion of value to the wheat received only $16 \%$ of the profit margin. The traders (collectors, wholesalers, and retailers) jointly shared $33 \%$ of the profit margin and the remaining $51 \%$ of the profit margin goes to processors.

The $\mathrm{CR}_{4}$ assessments in the major wheat markets along the chain noted that overall the whole wheat markets assessed across the chain were neither perfectly competitive nor tight oligopoly; they were just between monopolistic competition and loose oligopoly. In the markets near to the producers the four big traders control over the market was less as compared to the central wheat markets. The $\mathrm{CR}_{4}$ in Etaya (26.8) and Asala (37.7) were below $40 \%$ (monopolistic competition) compared to the $\mathrm{CR}_{4}$ at Adama (41.4) and Finfinnee (42.8) which fits to loose oligopoly market structure. Assessment on the degree of clearness or access to market information noted that the chain actors used various sources of information regarding the wheat market. However, majority (about 54\%) of the chain actors noted that it was very difficult to get reliable information about the whole wheat market along the chain, from local to central markets. Bureaucratic licensing procedure, lack of capital, and competitions were reported as barriers to entry to wheat market in the area. 
The study identified for all producers and retailers their only means of agreement in doing business with their transaction partners were spot-market agreement. The same is true for collectors on agreement with their suppliers. However, $63 \%$ and $16 \%$, of collectors had oral and written contractual agreements, respectively, with their buyers. Wholesalers and processors revealed relatively better establishing relationships with their transaction partners. $36 \%$ and $31 \%$ of wholesales responded they had oral contracts with their suppliers and buyers, respectively; $18 \%$ and $12 \%$ of them had written contracts with suppliers and buyers, respectively. Similarly, $42 \%$ and $9 \%$ of the processors had oral agreement with their suppliers and buyers while 23 and $27 \%$ of them had written contract agreement with their suppliers and buyers, respectively.

The study noted that the wheat chain assessed was characterized by disintegrated chain where businesses were self-oriented and mutualism has never developed. The study result showed that it was very difficult to get reliable information about the whole wheat market from local to central markets and proper business partner (customer) with whom to transact on a sustainable manner. Moreover, it was difficult for the business partners to agree on conditions of long-standing contracts. The assessments on the respondents' relationships with their major business partner showed there were no significantly different relationships between major customers and other ordinary customers. For most of the respondents there was no difference in frequency of transaction between the major partner and the others, those having contracts reported they usually betray the contract easily, there were no long-time established cooperation among the business with their major partners, trust was not well developed, there were no established and dependable logistics system that could ensure the product supply among the business partners. In general, dependable and trusting wheat supply chain was not developed.

Working towards supply chain management and relational view of business has been recommended based on the problems identified in the study. The chain actors need support to gear towards the business idea of overall chain value maximization as opposed to the ruthless effort for self-profit including at others' cost.

\section{References}

Aysheshm, K. (2007). Sesame market chain analysis: The case of Metema Woreda, North Gondar zone, Amhara national regional state. Haramaya University. Retrieved from https://cgspace.cgiar.org/handle/10568/3165

CIA. (2016). CIA World Fact Book. Central Intelligence Agency.

CSA. (2012/13). Agricultural SampleE Survey: Area and Production of Major Crops. The Federal Democratic Republic of Ethiopia, Central Statistical Agency.

Demeke, M., \& Di Marcantonio, F. (2013). Analysis of incentives and disincentives for teff in Ethiopia. Technical Notes Series. Retrieved from https://agriknowledge.org/downloads/tt44pm88r

Dessalegn, G., Jayne, T., \& Shaffer, J. (1998). Market structure, conduct, and performance. Constraints on Performance of Ethiopian Grain Markets, 8, 12. Retrieved from https://ideas.repec.org/p/ags/midcwp/ 55597.html

FAO. (2014). Analysis of price incentives for wheat in Ethiopia for the time period 2005-2012. In M. B. Wakeyo, \& B. Lanos (Eds.), Technical notes series, MAFAP. Food and Agriculture Organization of the United Nations. Retrieved from https://agriknowledge.org/downloads/dr26xx48c

FAO. (2016). FAO Statistical Year Book. Food and Agriculture Organization of the United Nations. Retrieved from http://www.fao.org/3/a-i4691e

Godfray, H. C. J., Beddington, J. R., Crute, I. R., Haddad, L., Lawrence, D., Muir, J. F., ... Toulmin, C. (2010). Food security: The challenge of feeding 9 billion people. Science, 327, 812-818. https://doi.org/10.1126/ science. 1185383

Harris, K. L., \& Lindblad, C. J. (1978). Post-harvest grain loss assessment methods. Minnesota, America Association of Cereal Chemist, 193.

Hellin, J., Lundy, M., \& Meijer, M. (2009). Farmer organization, collective action and market access in Meso-America. Food Policy, 34, 16-22. Retrieved from http://www.sciencedirect.com/science/article/pii/ S0306-9192(08)00075-4

Hodges, R. J., Buzby, J. C., \& Bennett, B. (2011). Postharvest losses and waste in developed and less developed countries: Opportunities to improve resource use. The Journal of Agricultural Science, 149, 37-45. https://doi.org/10.1017/S0021859610000936

Israel, G. D. (1992). Determining sample size. University of Florida Cooperative Extension Service, Institute of Food and Agriculture Sciences, EDIS. 
Junqueira, R. V. (2010). Governance structure and supply chain management practices in the dairy value chain: A comparative study between New Zealand and Brazil (A thesis presented in partial fulfilment of the requirements for the degree of Master of Logistics and Supply Chain Management at Massey University, Auckland, New Zealand). Retrieved from http://mro.massey.ac.nz/handle/10179/2263

Kaplinsky, R., \& Morris, M. (2001). A handbook for value chain research. IDRC Ottawa. Retrieved from https://www.ids.ac.uk/ids/global/pdfs/VchNov01.pdf

Kasa, L., Gashaw, A., \& Rashid, S. (2015). Wheat in Ethiopia: Production, marketing, and consumption.

Kathryn Bergh, A. C., Mary, K. G., \& Leigh, A. (2012). Wheat Value Chain: Ethiopia. EPAR Brief No. 204. Evans School of Policy Analysis and Research (EPAR).

Kummu, M., De Moel, H., Porkka, M., Siebert, S., Varis, O., \& Ward, P. (2012). Lost food, wasted resources: Global food supply chain losses and their impacts on freshwater, cropland, and fertiliser use. Science of the Total Environment, 438, 477-489. https://doi.org/10.1016/j.scitotenv.2012.08.092

Lambert, D. M., \& Cooper, M. C. (2000). Issues in supply chain management. Industrial Marketing Management, 29, 65-83. https://doi.org/10.1016/S0019-8501(99)00113-3

Lipinski, B., Hanson, C., Lomax, J., Kitinoja, L., Waite, R., \& Searchinger, T. (2013). Reducing food loss and waste. World Resources Institute Working Paper.

Mena, C., \& Stevens, G. (2010). Delivering performance in food supply chains. Elsevier. https://doi.org/ $10.1533 / 9781845697778$

Mendoza, G. (1995). A Primer on Marketing Channels and Margins. Prices, Products, and People: Analyzing Agricultural Markets in Developing Countries, 257.

Naldi, M., \& Flamini, M. (2014). The $\mathrm{CR}_{4}$ index and the interval estimation of the Herfindahl-Hirschman Index: An empirical comparison. SSRN 2448656. https://doi.org/10.2139/ssrn.2448656

Parfitt, J., Barthel, M., \& Macnaughton, S. (2010). Food waste within food supply chains: Quantification and potential for change to 2050. Philosophical Transactions of the Royal Society B: Biological Sciences, 365, 3065-3081. https://doi.org/10.1098/rstb.2010.0126

Pomeroy, R., \& Trinidad, A. (1995). Industrial organization and market Analysis: Fish marketing. Prices, products and people: Analyzing Agricultural Markets in Developing Countries.

Power, D. (2005). Supply chain management integration and implementation: A literature review. Supply Chain Management: An International Journal, 10, 252-263. https://doi.org/10.1108/13598540510612721

Rehima, M. (2006). Analysis of Red pepper marketing: The case of Alaba and Silte in SNNPRS (MSc thesis presented to the school of graduate studies of Haramaya University, Ethiopia). Retrieved from https://cgspace.cgiar.org/handle/10568/719

Rembold, F., Hodges, R., Bernard, M., Knipschild, H., \& Léo, O. (2011). The African Postharvest Losses Information System (APHLIS). European Union, Luxembourg.

Rosen, S., Meade, B., Fuglie, K., \& Rada, N. (2014). International Food Security Assessment, 2014-24. Economic Research Service, United States Department of Agriculture. Retrieved from http://www.ers.usda.gov/media/1499869/gfa25_final-0708. pdf

Stank, T., Crum, M., \& Arango, M. (1999). Benefits of interfirm coordination in food industry supply chains. Journal of business logistics, 20, 21.

Taylor, D. H. (2005). Value chain analysis: an approach to supply chain improvement in agri-food chains. International Journal of Physical Distribution \& Logistics Management, 35, 744-761. https://doi.org/ $10.1108 / 09600030510634599$

Tobin, J. (1958). Estimation of relationships for limited dependent variables. Econometrica: Journal of the Econometric Society, 24-36. https://doi.org/10.2307/1907382

Tomlinson, I. (2013). Doubling food production to feed the 9 billion: A critical perspective on a key discourse of food security in the UK. Journal of Rural Studies, 29, 81-90. https://doi.org/10.1016/j.jrurstud.2011.09.001

Van Der Vorst, J. G., Da Silva, C. A., \& Trienekens, J. H. (2007). Agro-industrial supply chain management: concepts and applications. FAO. 
Vorst, J., Beulens, A. J., Wit, W. D., \& Beek, P. V. (1998). Supply chain management in food chains: Improving performance by reducing uncertainty. International Transactions in Operational Research, 5, 487-499. https://doi.org/10.1111/j.1475-3995.1998.tb00131.x

WFP. (2014). Hunger Map of 2014. World Food Programme.

Wolday, A. (1994). Food Grain Marketing Development in Ethiopia after Reform 1990: A Case Study of Alaba Siraro (p. 293, The PhD Dissertation Presented to Verlag Koster University, Berlin).

Wooldridge, J. (2012). Introductory econometrics: A modern approach, Cengage Learning.

\section{Appendix}

Appendix 1. IM-test for checking Heteroscedasticity

\begin{tabular}{llll}
\hline Imtest- Cameron \& Trivedi's decomposition of IM-test & & & \\
\hline Source & $\mathrm{Ch} 2$ & $\mathrm{df}$ & $\mathrm{P}$ \\
Heteroscedasticity & 79.66 & 114 & 0.1516 \\
Skewness & 20.87 & 14 & 0.0959 \\
Kurtosis & 1.17 & 1 & 0.2785 \\
Total & 101.7 & 129 & 0.175 \\
\hline
\end{tabular}

Note. Imtest- indicates that there is no serious problem of heteroscedasticity, since value is insignificant. 


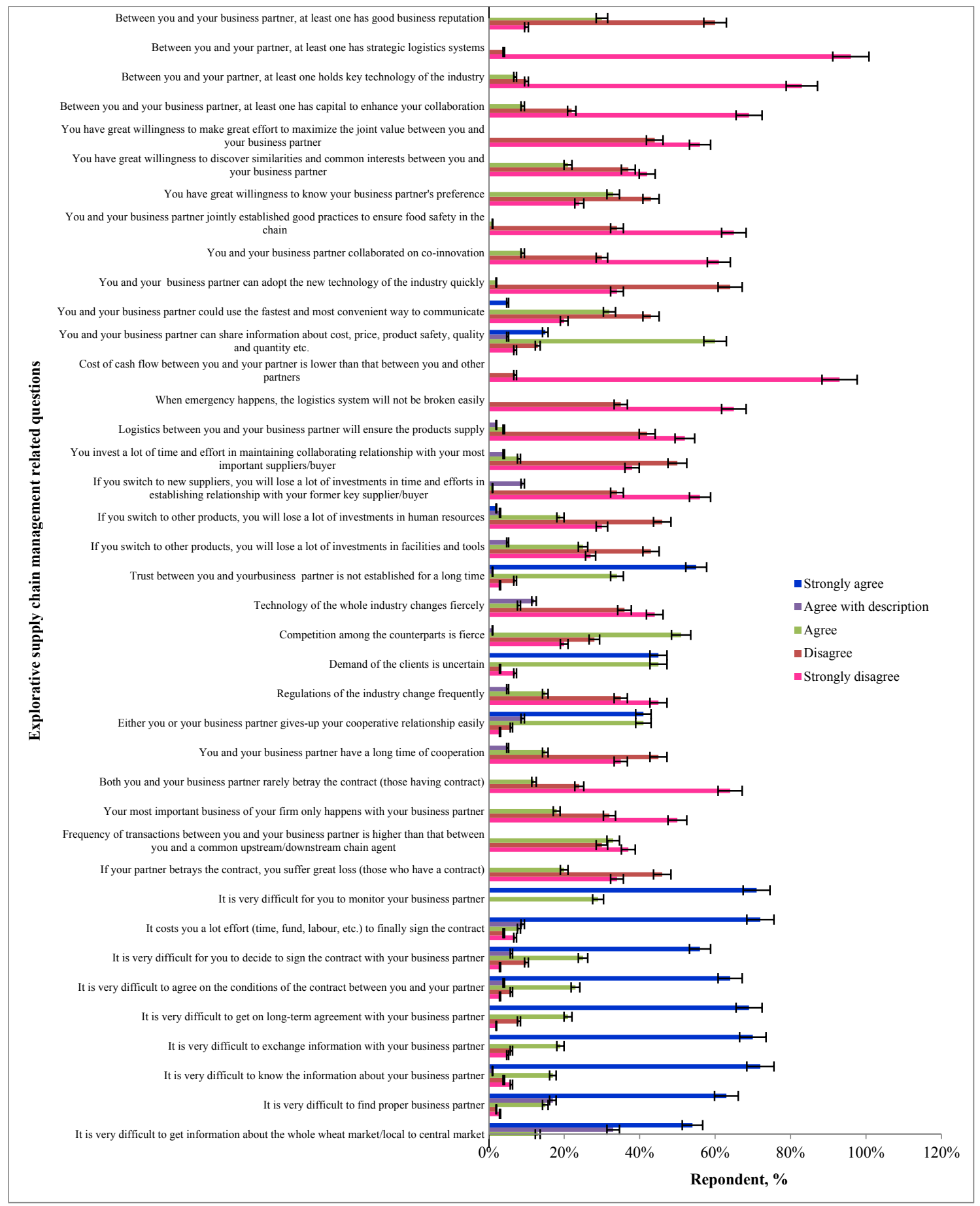

Appendix 2. Situation of supply chain management and relationships among chain actors in the wheat value chain $(5 \%$ error bar)

\section{Copyrights}

Copyright for this article is retained by the author(s), with first publication rights granted to the journal.

This is an open-access article distributed under the terms and conditions of the Creative Commons Attribution license (http://creativecommons.org/licenses/by/4.0/). 